
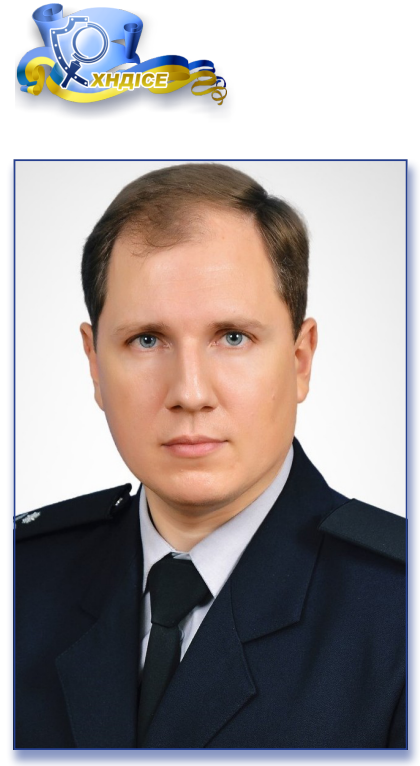

Орлов

Юрій Вомодимирович
Фронтир

як категорія кримінологічного дискурсу

\section{УАК 343.41}

Юрій Володимирович Ормов,

доктор юридичних наук, професор, професор кафелри кримінального права і криміномогії факультету № 1 Харківського національного університету внутрішніх справ, м. Харків, Україна

ORCID ID: http://orcid.org/0000-0003-1981-0794

e-mail: orlov1284@ukr.net

\section{Фронтир}

\section{як категорія кримінологічного дискурсу}

Постановка наукової проблеми. Прийнято вважати, що, починаючи з другої пол. XX ст., світ, увійшовши в цивілізаційний часопростір Постмодерну, набув фрактального вигляду, ризоматичної будови. Точніше був явлений у мисленнєвих просторах як такий, що поступово, із все більшою наочністю відобразилось у дійсності, не в останню чергу - як результат принципового заперечення можливості практичного зв'язку (принаймні у сфері політики) метафізики та онтології, прагнення створити запобіжники тотальності (в тому числі - тоталітаризму), кічу у будь-якому вигляді. I хоча не вдалося повною мірою позбутися ані першого, ані другого із бажаних об'єктів запобігання, дробність соціального світоустрою досягла раніше не бачених масштабів. Дається взнаки і капсуляція мислення в межах мезо- та мікронаративів (групова ідентичність на основі "лун-камер", рос. - "эхо-камер"), і пришвидшення соціального часу, втрата актуальності передачі вагомого обсягу знань від одного покоління до іншого тощо. В таких умовах знову набуває значення дослідження фронтирів як пограничних зон, в яких відбувається дифузія соціально-групових відмінностей, взаємодія різних культур, наративів, зрештою - зіткнення цивілізацій. Ці зони насичені конфліктами різної природи, генези, відтворення яких часто містить істотний криміногенний потенціал, проявлену фронтирну злочинність. Притому вони мають не стільки фізично-просторовий, географічний (хоча й у топосі, як правило, вказані зони також візуалізовані), скільки соціально-часовий вимір, простори буття якого розгортаються у сфері дискурсу, мислення, забезпечені розгалуженою, глобальною телекомунікаційною інфраструктурою.

Надто актуальною загальносоціальна та кримінологічна проблема фронтирів виявляється для нашої країни. Україна, зазначає С. М. Плохій, завжди була прикордонною зоною між євразійськими степами, де жили кочовики, і заселеними лісовими територіями. Київ, майбутню столицю України, засновано як прикордонний пост між цими двома світами. Боротьба за виживання зі степовиками та подальша колонізація степу - одна з найважливіших тем української історії, хоч історія "рухливого кордону" України - місця взаємодії держав, поселенців і кочовиків - так і не знайшла свого Фредерика Джексона Тернера чи Герберта Юджина Болтона ${ }^{1}$ I сьогодні Україна є місцем на кордоні кількох культурних просторів. Таке розташування допомогло зробити її контактною зоною, в якій українці різних віросповідань змогли навчитися співіснувати. Воно також допомогло створити регіональні поділи, які експлуатуються учас-

\footnotetext{
Plokbii, S. M. (2011) Mizh istoriieiu ta natsiieiu: Pavlo Robert Magochii i pereosmyslennia ukrainskoi istorii [Between History and the Nation: Pavlo Robert Magochiy and Rethinking Ukrainian History]. Krytyka [Criticism], Zhovten [October]. Retrieved from https://krytyka. $\mathrm{com} / \mathrm{ua} /$ articles/mizh-istoriieyu-ta-natsiieyu-pavlo-robert-magochiy-i-pereosmyslennya-ukrayinskoyi-istoriyi [in Ukrainian]. (2020, March, 15).
} 
никами сучасного конфлікту. Україна завжди була відома культурною гібридністю свого суспільства, але наскільки довго нація може нести цю гібридність залишатися єдиною перед обличчям гібридної війни - є одним з важливих питань, що наразі вирішується у конфлікті між Росією та Україною².

Аналіз основних досліджень і публікацій. Проблеми появи, існування, руху фронтирів традиційно входили до предметного кола історії, культурології, антропології. Класичними вже стали праці Х. Болтона (H. E. Bolton), M. С. Грушевського, Я. Дашкевича, В. В. Кравченка, Г. Ламара (H. Lamar), Ф. Дж. Тернера (F. J. Turner), Л. Томсона (L. Thompson), Л. Февра (L. Febvre), К. Фіша (K. Fish), Р. Хофітендера (R. Hofstadter), A. Чендлера (A. Chandler), I. П. Чорновола та ін. В кримінологічній же науці ця проблематика до теперішнього часу практично залишалася непоміченою. Існує, певна річ, низка досліджень, пов'язаних з транскордонною злочинністю. Однією з останніх подібних робіт було докторське дисертаційне дослідження за темою "Кримінологічні засади протидії транскордонній злочинності" й тематично відповідна монографія під авторством С. О. Філіппова ${ }^{3}$. Однак в цьому, як і в низці інших суміжних досліджень, фронтир, якщо і згадується, - то лише як синонім кордону в його політико-територіальному, конституційно-правовому розумінні, але не більше того. Тож можна вважати, що як елемент кримінологічного дискурсу категорія "фронтир" $є$ нерозробленою.

Mema cmammi - встановити, надати опис та пояснення змісту категорії "фронтир" як елементу кримінологічного дискурсу, визначити особливі риси феномену фронтирної злочинності.

Виклад основного матеріалу. Давньогрецька філософська традиція позначала фронтиром лінію розмежування між пізнаним греками світом, ойкуменою (ойкосом), та невідомістю, варварськими землями. Давньоримська культура оперувала латинським терміном "fronteria" у значенні передньої частини чого-небудь, що відповідає сучасному французькому "frontiere".

У більшості англо-українських, англо-російських словників "frontier" визначається як кордон. Але для точнішого уявлення про дійсний зміст вказаної категорії, що узвичаївся у культурологічній, соціологічній, лінгвістичній традиції та претендує (має на це всі передумови) на використання у кримінології, доцільно звернути увагу й на її англо-американську конотативність. Остання ж неодмінно пов'язується із “...гстрим краєм суверенітету, одномірним розрізненням націй між своїм та чужим... Цей термін асоціюється із часами дикого (Великого) Заходу, образами критих візків, кіньми, зброєю та напруженістю, пов'язаною із зіткненням європейських колонізаторів з індіанською культурою, із необхідністю розширення впливу... кожна цивілізація має свої межі, що виникли у боротьбі..." ${ }^{4}$. Таким чином, переклад українською англійського "frontier" чи більш раннього його латинського аналогу (та інших відповідників ${ }^{5}$ ) лише як "кордон" видається не повною мірою обгрунтованим, адже невиправдано звужує вельми широке культурологічне та похідне

Plokbii, S. M. (2016) Brama Yevropy: istoriia Ukrainy vid skifskykh voien do nezalezhnosti [The Gates of Europe: History of Ukraine from the Scythian Wars to Independence]. Kharkiv, Knyzhkovyi klub, 452-453 [in Ukrainian].

Filippov, S. O. (2019) Protydiia transkordonnii zlochynnosti: hlobalnyi kontekst ta realii Ukrainy: monohrafiia [Combating cross-border crime: the global context and realities of Ukraine]. Odesa. Feniks [in Ukrainian].

Chandler, A. Comparing Frontiers: A Scout Report. Retrieved from http://www.arthurchandler. com/comparing-frontiers [in English]. (2020, March, 15).

В арабській мові: hadd (віА «різати») - «вістря меча» - буквально, «край будь-чого» - взагалі, авангард військового фронтиру; tagr (pluralis - tugur) - буквально «передні ікла пса», marca paganorum (іспанський еквівалент - Extremadura), прохіА на кордоні; саwasim - гінтерлянА; Dar al-Islam - світ мусульман, Dar al-Harb - зона священної війни проти невірних. У польській мові: marchia, Ukraina, Dzikie Pola (Аикі Поля, прийшло з італійських мап XVII ст.:

\section{Ю. В. Ормов}

\section{ФРОНТИР ЯК КАТЕГОРІЯ КРИМІНОАОГІЧНОГО}

\section{АИСКУРСУ}

Конвергенція тенденцій глобалізації та глокамізації у розвитку світу загалом та різного масштабу соціальних груп у межах окремих Аержав, зокрема, подацьша фрагментація та капсуляція наративів, Аискурсивних систем актуалізує кримінологічну проблематику фронтирів.

Мета статті полягає у виявАенні, описі й поясненні змісту категорії «фронтир» як елементу кримінологічного Аискурсу.

Установ ено, що фронтири є зонами соціокультурного зіткнення, активної взаємодіі контроверсійних цивілізаційних зразків із претензійністю на Аомінування, експансію та захист. Ці позиціі та установки соціальної Аія ьності часто реалізуються у кримінальних формах, що ставить на порядок Аенний питання про вивчення сутності фронтирної зАочинності, розробку заходів зниження факторів її детермінації, зокрема ресентименту.

КАючові слова: фронтир, соціальний сценарій, наратив, Аискурс, символіка, зАочинність, ворожнеча.

\section{Y. Orlov}

FRONTIER AS A CATEGORY OF CRIMINOLOGICAL DISCOURSE

The significance of frontiers has been actualizing in the modern world as border zones, in which there is a diffusion of social and group differences, interaction of cultures, narratives, clash of civilizations. These areas are filled with conflicts of diverse nature, genesis, reproduction of which often contains significant criminogenic potential, manifested frontal crime. They have not as much a physical spatial, geographical, as a socio-temporal dimension, the spaces of existence of which unfold in the sphere of discourse, thinking, and are provided with an extensive, global telecommunication infrastructure.

The purpose of the article is to establish, describe and explain the content of the category "frontier» as an element of criminological discourse.

The frontier is defined as a border and borderzone between cultures, epochs in the actual calendar, 


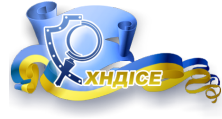

physical time; it is a place of active interaction, clash of civilizations, cultures; the opposition, determined by the state of struggle, implicitly presupposes expansion and protection, a state of hostility, anxiety, and sacrifice. Frontier crime is a type of crime determined by conflicts in the area of social frontiers. Specific evidence of committing frontal crime: 1) it's a conflict of identities; 2) has a political and/or religious motivation, however security-dominant and solidarity motivation; 3) aggressive and violent in nature; 4) depends on historical and/or religious-dogmatic (fundamentalist) consciousness, relies on the mechanisms of postmemory, radicalized discourse, actualized memes, symbols. In the global dimension, the implementation of frontal crime is explained by the mechanisms of the development of conflict between cultures. In the national - there have been identified three types of frontier crime: transitive, immanent, and postmodern anomie.

Operating the frontier as a category of criminological discourse provides opportunities for a deeper study of the determination of political crime in Ukraine, as well as for the development of strategies for general social development (including in the context of combating crime) taking into account the socio-cultural frontier. Perspective areas of criminological research of the frontier is the study of the influence of the border and cross-border on the promotion of extremism terrorism, taking into account its importance while designing and implementing the concept of transitional justice, as well as the peculiarities of constitution of frontie identity as an anti-criminal basis.

Keywords: frontier, social scenario, narrative, discourse, symbolism, crime, hostility.

\section{Y. Orlov}

GRENZLAND ALS

KRIMINALISTISCHE

DISKURSKATEGORIE

In der heutigen Welt ist die Bedeutung von Grenzländern als Grenzzonen aktuell, in denen die Diffusion der Sozialgruppenunterschiede, die Wechselwirkung von Kulturen, Erzählungen und der Konflikt von Zivilisationen vorgekommen werden. Diese Zonen haben sehr viele Konflikten verschiedener Art und Genesis, deren Entstehung häufig ein erhebliches kriminogenes Potenzial und das entwickelnde Grenzlandkriminali-
Фронтир

як категорія кримінологічного дискурсу

від нього кримінологічне значення. $€$ необхідність у використанні ідентичної, гносеологічно самостійної семантичної категорії "фронтир".

Фронтир - кордон та прикордоння між світами, культурами, епохами в актуальному (одному) календарному, фізичному часі. Це - місце активної взаємодії, зіткнення цивілізацій, культур. І місце це - опозиційне, визначене станом боротьби, імпліцитно передбачає експансію та захист, стан ворожості, тривожності, жертовності. Це місце - міфологізоване, визначає бінарну опозицію, матрицю сприйняття, соціального орієнтування, в якій той самий кордон, межа виконують функцію групової консолідації, солідаризації у протиставленні, відмежуванні та, таким чином, визначенні ідентичності.

Кордон, небезпідставно зазначає О. В. Берднікова, є важливим чинником у формуванні спільнот; організація і оформлення кордону, правил його перетину, уявлень про нього відображають внутрішні характеристики співтовариств, які ця межа "обрамляє". Китайська стіна або "залізна завіса" як матеріалізовані і метафоричні перепони є породженням своїх епох і своїх культур 6 . Державний кордон в СРСР відігравав надзвичайно важливу роль в конституюванні радянського суспільства. Він не тільки визначав "свою" територію, відгороджував "чужих" і позначав конфронтацію політичних систем на глобальному рівні, а й виконував універсальну функцію, володів вичерпністю смислів - від політичних до метафізичних. Він став мірою, що орієнтує всю організацію життя. Наприклад, аналізуючи архітектурне будівництво в Москві 20-30-х років, В. З. Паперний зазначає (мовою оригіналу): „Удивительно, как точно фиксируют архитекторы на своем пространственном языке вдруг выросшие повсюду барьеры и границы" ${ }^{7}$. Можна стверджувати навіть про тотальність метафори кордону в Радянському Союзі, що широко відобразилось й у масовій культурі (популярна в 30-ті роки пісня (мовою оригіналу): “Эй, вратарь, готовься к бою! / Часовым ты поставлен у ворот. / Ты представь, что за тобою / Полоса пограничная идет") ${ }^{8}$. Відтак, влучно підмічає Д. С. Панаріна, кордон досить часто створює довкола себе дієвий соціальний міф, який презентує фронтир ${ }^{9}$.

Однак у сучасному світі з розвиненими формами масової комунікації, ефектами глобалізації, що в значній мірі (за нормальних, не екстремальних умов) елімінують значення державних кордонів, фронтитири мають властивість виникати на інших, не фізичних рівнях соціально-групових взаємодій. Вони представлені межами соціальних сценаріїв, наративів, дискурсів, знаково-символічних, меметичних систем. Межі ці мають як географічні, так і позагеографічні контури фіксації. При цьому важливо бути свідомим тієї обставини, що, будучи емоційно резонансними, суб'єктивно значущими обрисами інтерактивних матриць, в межах яких відбувається соціальна ідентифікація, привласнення й ретрансляція досвіду (пам'яті, постпам'яті - у термінології М. Хірш) попередніх поколінь як власного, фронтити постають зонами актуалізації бінарних опозицій. Для бінарних же опозицій (“сіій - чужий", "Схід - Захід", "проукраїнський - проросійський", "патріот - сепаратист" і т.д.) властивим є

Campi Deserti): Chornovol, I. (2015) Komporatyvni frontyry: svitovyi i vitchyznianyi vymiry [Comparative frontiers: world and domestic dimensions]. Kyiv, Krytyka, 30 [in Ukrainian].

Berdnikova, O. V. (2002) Poslednik rubezh? [The Last Frontier]. Otechestvennyie zapiski [Domestic notes], 6 (7). Retrieved from http://www.strana-oz.ru/2002/6/posledniy-rubezh [in Russian]. (2019, October, 12).

Papernyiy, V. Z. (1996) Kultura Dva [Culture Two]. Moskva, Novoe literaturnoe obozrenie, 79 [in Russian]

Berdnikova, O. V. (2002) Poslednik rubezh? [The Last Frontier].

Panarina, D. S. (2015) Granitsa i frontir kak faktor razvitiva regiona i/ili stranyi [Border and frontier as a factor in the development of a region and / or country]. Istoriya i sovremennost [History and Modernity], 1 (21). Retrieved from https://www.socionauki.ru/journal/articles/265432/ [in Russian]. (2019, October, 15). 
відношення не констеляції, а субординації, ієрархії. Звідси - й прагнення до домінування, підкорення. Тож фронтири завжди постають як результат та, в той же час, фактор детермінації різниці потенціалів (відмінностей на рівні соціальних конвениій про ідентичність, оцінки минулого, теперішнього та майбутне), а тому несуть на собі зарла соціальної напруженості, конфліктогенності, криміногенності.

Фронтири ніколи не виникають ізольовано, а винятково у взаємодії відмінних соціокультурних систем. Вони є функцією розрізнення та забезпечення безпеки, збереження автохтонності. В цьому сенсі політика мультикультуралізму виявляється політкоректною спробою налагодження діалогу та порозуміння в умовах прямих, безпосередніх контактів у середовищі фронтиту(ів). Однак, коли питання переводиться у русло конкуренції (за соціальну допомогу, робочі місця, територію проживання, зрештою - політичну стратегію), мультикультуралізм руйнується. Єдине, що його підтримує - кримінальний закон й кволі, непереконливі апеляції до ліберально-гуманістичних ідеалів, які на практиці цілком очікувано набувають імітаційних, вибіркових форм, симуляцій, властивих для суспільств спектаклю (у концепції Е. гі Дебора ${ }^{10}$ ).

Оскільки фронтири є функціями розрізнення, як складові забезпечення безпеки, остільки ж і злочинність, що виникає як форма перебігу фронтирних конфліктів, є цілком функціональною, виражає спрямованість на збереження ідентичності й захисту дійсних (конвенційних) чи удаваних (міфологізованих, сугестивних) групових цінностей, реалізації відповідних потреб. Саме тому в переважній своїй частині фронтирна злочинність представлена як злочинність політична, кримінальна, свавільна форма прояву суверенних моментів.

В той же час існування фронтиру зумовлює активне відтворення феномену ресентименту, але не у значенні прямої агресивної відповіді на загрози ін-групи з боку аут-групи. В цьому контексті звертає на себе увагу важлива теза Ф. Дж. Тернера (щоправда, її здебільшого розвинули його послідовники) - доктрина "випускного клапана" (safety-valve doctrine). Науковець спостеріг, що наявність вільних земель водночас сприяла розв'язанню соціальних проблем, тому США, на противагу Європі, вдалося уникнути гострих форм класової боротьби ${ }^{11}$. Проте, функція "випускного клапану", або сублімації соціальної енергетики в умовах фронтиру спрацьовує тільки тоді, коли для цього є вільний ресурс, простір. Останній здебільшого пов'язується з географічними підставами розсіювання агресії, як в умовах американської колонізації. Інакше - відбувається нарощування ворожнечі, агресивного потенціалу (агресія як результуюча звуження простору - crowding), що "розряджається" механізмами ресентименту, тобто через генерацію, підтримання наративів і дискурсу ідентичності у повністю або частково сфальсифікованих умовах протистояння загрозам існування групи, що супроводжується агресивними практиками опозиційно-консолідуючого значення.

Важливо наголосити, що ресентимент породжується тільки там, де $€$ фальсифікація. В цьому, власне, його зміст і основне функціональне призначення як "громовідводу". Йдеться про конструювання аут-групи як доступного до сприйняття, зрозумілого об'єкту спрямування агресії, зумовленої факторами іншого порядку, основне поле відтворення яких не має прямого відношення до відповідної аут-групи. Базою такого конструювання є дискурсивні дегуманізаційні, деперсоналізаційні практики, насичені мовою ворожнечі. Вони обов'язково підкріплюються соціальною міфологією, що розвивається й поширюється каналами та механізмами формування, стимулювання постпам'яті у колективно-емо-

Debor, E. (1999) Obschestvo spektaklya [Performance society]. Moskva, Logos [in Russian].

1 Chornovol, I. (2015) Komporatyvni frontyry: svitovyi i vitchyznianyi vymiry [Comparative frontiers: world and domestic dimensions], 39 . tät enthält. Sie haben nicht nur eine physisch- räumliche, geografische, sondern vielmehr eine soziozeitliche Dimension, deren Daseinraum sich in Diskurbereichen und in Denken entwickeln und mit einer umfassenden globalen Telekommunikationsinfrastruktur versorgt sind.

Das Ziel der Abhandlung ist es, den Inhalt der Kategorie „Grenzland" als Element des kriminologischen Diskurses festzustellen, zu beschreiben und zu erläutern.

Das Grenzland ist definiert als die Grenze zwischen Kulturen, Epochen in der aktuellen kalendermäßigen, physischen Zeit; es ist ein Ort der aktiven Interaktion, des Konflikts der Zivilisationen, der Kulturen; Opposition, die durch den Zustand des Kampfes festgesetzt ist, setzt eine Expansion und eine Verteidigung, den Zustand der Feindseligkeit, der Ängstlichkeit und der Opferwilligkeit implizit voraus. Grenzlandkriminalität ist eine Art von Kriminalität, die durch Konflikte in der Zone sozialer Grenzländer determiniert ist. Besonderheiten der Grenzlandkriminalität: 1) ist ein Identitätskonflikt; 2) hat eine politische und / oder religiöse Motiviertheit, aber eine sicherheitsdominante und solidarische Motivation; 3) ist aggressiv-gewalttätig; 4) hängt vom historischen und / oder religiös-dogmatischen (fundamentalistischen) Bewusstsein $a b$, stützt sich auf Postmemory-Mechanismen, radikalisierten Diskurs, aktualisierte Memes, Symbole. In der globalen Dimension wird die Nachbildung der Grenzlandkriminalität durch die Mechanismen der Entwicklung des Kulturkonflikts erklärt. In der nationalen Dimension werden drei Arten der Grenzlandkriminalität eruiert: transitiv-, immanent- und postmodern-anomisch

Die Behandlung des Grenzlandes als der Kategorie des kriminologischen Diskurses eröffnet Möglichkeiten für eine eingehendere Untersuchung der Determination der politischen Kriminalität in der Ukraine sowie für die Ausarbeitung von Strategien für die gemeinsam soziale Entwicklung (auch im Zusammenhang mit der Kriminalitätsbekämpfung) unter Berücksichtigung des Faktors der soziokulturellen Grenze. Perspektivgebiete der kriminologischen Grenzlanduntersuchung ist die Erforschung des Einflusses von der Grenze auf die Förderung von Extremismus und Terrorismus, der Erfassung seiner Bedeutung für die Projektierung und Verwirklichung des Konzepts der Übergangsge- 


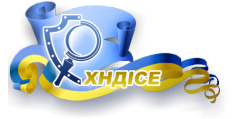

rechtigkeit sowie der Besonderheiten der Konstituierung der Grenzlandidentität als antikriminalistischer Grundlage.

Schlüsselwörter: Grenzland, soziales Szenario, Erzählung, Diskurs, Symbolik, Kriminalität, Feindschaft.

\section{Y. Orlov}

\section{FRONTIER COMME}

CATÉGORIE DE DISCOURS CRIMINOLOGIQUE

Dans le monde moderne, l'importance des frontières en tant que zones frontalières est actualisée, dans laquelle il y a une diffusion des différences sociales et de groupe, l'interaction des cultures, des récits, le choc des civilisations. Ces zones sont pleines de conflits de nature diverse, de genèse, dont la reproduction contient souvent un potentiel criminogène important se manifestant par un crime frontalier. Ils ont moins une dimension physique spatiale, géographique, que sociotemporelle, dont les espaces d'existence se déploient dans le domaine du discours, de la pensée, sont dotés d'une infrastructure de télécommunications globale et ramifiée.

L'objectif de l'article est d'établir, de décrire et d'expliquer le contenu de la catégorie "frontière" en tant qu'élément du discours criminologique.

La frontière est définie comme la frontière et la frontière entre les cultures, les époques du calendrier réel, le temps physique; c'est un lieu d'interaction active, de choc des civilisations, des cultures; l'opposition, déterminée par l'état de lutte, suppose implicitement l'expansion et la protection, un état d'hostilité, d'anxiété et de sacrifice. Le crime frontalier est un type de crime déterminé par des conflits dans le domaine des frontières sociales. Signes spécifiques de criminalité frontalière: 1) est un conflit d'identités; 2) a une motivation politique et/ou religieuse, mais une motivation de sécurité et de solidarité; 3) par nature: agressivement violent; 4) dépend de la conscience historique et/ou religieusedogmatique (fondamentaliste) s'appuie sur des mécanismes postmémoire, un discours radicalisé, des mèmes actualisés, des symboles. Dans la dimension globale, la reproduction du crime frontal s'explique par les mécanismes de développement du conflit des cultures. Au niveau national
Фронтир

як категорія кримінологічного дискурсу

ційному діапазоні "жертовність - велич". 3 цього ж категоріально-емпатійного діапазону раціонально виводяться претензії на визнання, компенсації, домінування у визначеному просторі ${ }^{12}$.

Закономірності відтворення фронтирної злочинності (не називаючись такою) у глобальному вимірі в кримінологічній науці традиційно описуються з використанням аналітичної схеми теорії конфлікту культур (Т. Селлін, С. Хантінгтон та ін.). Її суть, як відомо, зводиться до пояснення причин злочинності крізь призму невідповідності культурних зразків світосприйняття та поведінки (системи релігійних, етичних, правових норм тощо) різних груп населення, які з тих чи інших причин вимушені проживати на одній території. Застосування теорії конфлікту культур дозволяє пояснити підвищену злочинну активності з одного боку, та підвищений рівень віктимності - $з$ іншого, серед представників деяких діаспор за межами країн свого корінного проживання: афроамериканців та пуерторіканців в США, арабів в Норвегії, Швеції та інших країнах $€_{\text {в- }}$ ропи тощо. Проте на початок XXI ст. таке пояснення видається завузьким і таким, що не відповідає всьому різнобарв'ю кримінальних проявів існування фронтирів у світі. У найбільш загальних рисах вони можуть бути виявлені при аналізі етнорелігійного тероризму, расизму й ксенофобії, кримінального протистояння політичних полюсів, що переноситься на територію, населення "третіх" країн.

У національному (внутрішньодержавному) вимірі фронтири формуються в гостро аномійних суспільствах: у тих, які можливо віднести до таких у зв'язку з: а) транзитивними станами; б) іманентною (історично зумовленою) аномійністю (притаманні мешканцям фронтиру амбівалентна ідентичність і, сказати б, роздерте сумління були актуальні в Україні не лише у XV-XVIII ст., а навіть у XX ст. ${ }^{13}$ і XXI ст. також); в) активним соціальним сприйняттям ефектів Постмодерну. В останньому випадку йдеться про пришвидшення часу та міжпоколінний розрив. Покоління не мають вожливості обмінюватись досвідом. Досвід старшого покоління багато в чому не $є$ адекватним запитам та умовам соціальної дійсності нового покоління. Тому постмодерні суспільства $€$ неісторичними (про що може казати сам факт існування музеїв сучасного мистецтва у Барселоні, Берліні, Відні, Вільнюсі та інших містах?) у традиційному, лінійному розумінні “історицизму" (час надто швидкий, сучасність вже $є$ історією, вже є тим, що було). Темпоральна структура постмодерних суспільств зруйнована втратою історико-культурних міжпоколінних зв'язків спадковості. Внаслідок цього особливо актуальним стає розвиток наук про дух, на які покладається функція компенсації неісторичності постмодерних суспільств. Але на рівні докси компенсація практично не відбувається; жити "своїм часом" стає розкішшю, що потребує постійної особистісної реінновації. Так виникають міжчасові (міжвимірні) постмодерні фронтири.

В українському суспільстві поєднуються і елементи транзитивності, і іманентної, і постмодерної аномійності. Перша (транзитивна аномія) визначається загалом відомими процесами руйнації комуно-соціалістичного метанаративу, намаганнями долучитися до капіталістичної, ліберально-демократичної традиції. В цілому цей різновид аномії описаний у численних кримінологічних дослідженнях та не потребує додаткових пояснень. Друга і третя - суперечностями соціально-часових розривів. При цьому ми свідомо поєднали іманентні й постмодерні аномійності че-

Orlov, Yu. V. (2020) Resentyment: shliakh vid zhertovnosti do zlochynnosti [Resentment: the way from victimity to crime]. Visnyk Kryminolohichnoi asotsiatsii Ukrainy [Bulletin of the Criminological Association of Ukraine]. 1 (22), 140-151 [in Ukrainian].

13 Chornovol, I. (2015) Komporatyvni frontyry: svitovyi i vitchyznianyi vymiry [Comparative frontiers: world and domestic dimensions], 263. 
рез їх інтегративні прояви та необхідність, у зв'язку з цим, відповідного аналізу.

Варто мати на увазі, що соціальний час як категорія, що відображає структуру багаточасовості в одночасному, тобто соціальної багатовимірності астрономічного часу, складається з трьох компонентів: наратив, дискурс та символіка. Як правило (принаймні щодо українського суспільства) ці складові соціального часу формують визначені соціальні сценарії - траєкторії суспільного розвитку зі фіксованою "слідовою картиною", ретроспективою та відповідною їй перспективою. У перекладі на площину кримінологічного аналізу злочинності в Україні це означає:

1) формування фронтирів на межі соціальних сценаріїв. Такі фронтири є умовно стабільними та зберігаються там, де соціальні сценарії не були "дограні" (а вони, як відомо з історії, завжди "дограються"). В. В. Кравченко в історіографічному аспекті простежив змагання трьох концепцій ідентичності - "радянсько-православної" ("донаціональної", "східнослов'янської), української етнокультурної (національної), “європейської" ("постнаціональної»)14. Тож в Україні співіснують щонайменше три сценарії, які фронтиризують наше суспільство (як і в період національно-визвольних змагань 1918-1922 рр., тобто фактично через 100 років ми знову опинилися в ідентичній міжсценарній ситуації): самостійницький, євроінтеграційний та імперський (проросійський), кожен з яких репрезентований особливими наративами, дискурсом, символічно-меметичними системами. У зв'язку з цим можна виділити фронтири проявляють себе:

- на межі наративів, що фіксуються як системо утворююче ядро відповідних сценаріїв. Наративи вміщують уявлення про благо, істину, соціальні конвенції з цих приводів, екстрапольовані на внутрішню, зовнішню, в тому числі й безпекову політики;

- на межі дискурсів. Оскільки мислення надане в мові, остільки ж дискурсивні простори формують, детермінують наративне мислення. Мислення (точніше, оперування дискурсивними засобами) у різних наративах (проросійсько-радянсько-героїзаторському ("сивушно-візантійському"), жертовно-войовничо-націоналістичному, меншовартісно-євроінтеграційному, окремих їх комбінаціях) визначає базову, історично зумовлену фронтирність українського суспільства. Позбутись її можливо виключно при переході від мислення історичного (повільного, епімеїстичного) до позаісторичного (інноваційного, прометеїстичного, категоріями майбутнього), якщо, звісно, йдеться не про позицію домінування. 3 цього має виходити і концепція перехідного правосуддя, і оновленого соціального договору;

- на межі соціальної символіки (мемів, образів, пам'ятників, фольклору), яка відсилає користувача (перцептанта) до відповідних дискурсів, наративів, сценаріїв.

Міжсценарні фронтити - найбільш небезпечні, підтримуються освітою, пропагандою, відповідною їй міфологією, апелюють до історичної пам'яті (неодмінно у емоційно резонансних опозиціях жертовності/героїзму, пригніченості/величі і т.д., з використанням властивих дискурсів, мемів), активно залучають механізми формування й стимулювання постпам'яті як необхідного чинника підтримання різниці потенціалів (за нормальних умов - це політичні дивіденди, електорат, а за умов війни соціальна база ворогуючих сторін). Такий соціальний стан - ідеальний для зовнішнього політичного управління, що реалізується, як засвідчує практика, через розпалювання ненависті, збройних конфліктів, постій-

14 Kravchenko, V.V., Musiezdov A. A., Filippova O. A. (2012) Predstavleniya o Pograniche i praktiki ih ispolzovaniya [Perceptions of the Borderland and the practice of their use]. Vilnyus, Evropeyskiy gumanitarnyiy universitet, 10-94 [in Russian]. trois types de délits frontaliers sont révélés: anomie transitive, immanente et postmoderne.

L'exploitation de la frontière en tant que catégorie de discours criminologique ouvre des opportunités pour une étude plus approfondie de la détermination de la criminalité politique en Ukraine, ainsi que pour l'élaboration de stratégies de développement social (y compris dans le contexte de la lutte contre la criminalité), en tenant compte du facteur de la frontière socioculturelle. Un domaine prometteur de la recherche criminologique de la frontière est d'étudier l'influence de la frontière et de la frontière sur la promotion de l'extrémisme, du terrorisme, en tenant compte de son importance dans la conception et la mise en œuvre du concept de justice transitionnelle, ainsi que des caractéristiques de la constitution de l'identité de frontière en tant que base anti-pénale.

Mots-clés: frontière, scénario social, narration, discours, symbolique, criminalité, hostilité.

\section{Ю. В. Ормов}

ФРОНТИР КАК КАТЕГОРИЯ КРИМИНОАОГИЧЕСКОГО АИСКУРСА

В современном мире актуа изируется значение фронтиров как пограничных зон, в которых происходит Аиффузия социа $ь-$ но-групповых разАичий, взаимодействие культур, нарративов, столкновение цивилизаций. Эти зоны насыщены конфликтами разнообразной природы, генезиса, воспроизведение которых часто содержит в себе существенный криминогенный

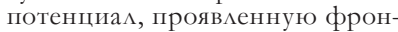
тирную преступность. Они имеют не столько физическое пространственное, географическое, сколько социально-временное измерение, пространства бытия которого разворачиваются в сфере Аискурса, мышления, обеспечены разветвлённой, глобальной телекоммуникационной инфраструктурой.

Цель статьи - установить, описать и объяснить содержание категории «фронтир» как элемента криминологического Аискурса.

Фронтир определён как граница и пограничье между культурами, эпохами в актуацьном календарном, физическом времени; это место активного взаимодействия, столкновения цивихизаций, культур; оппо- 


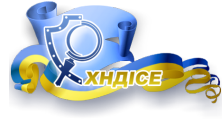

зиционное, определенное состоянием борьбы, имплицитно преАполагает экспансию и защиту, состояние враждебности, тревожности, жертвенности Фронтирная преступность - разновидность преступно сти, Аетерминированной кон фликтами в зоне социальных фронтиров. Специфические признаки фронтирной преступности: 1) яв яется конфииктом иАентичностей; 2) имеет политическую и/ими религиозную мотивированность, однако безопасностно-Аоминантную и соАидаризирующую мотивацию; 3) по характеру - агрессивно-насильственная; 4) зависит о исторического и/ими религиозно-догматического (фундаменталистского) сознания, опирается на механизмы постпамяти, радикализованный Аискурс, актуализированные мэмы, симво$\Lambda$ Ы. В глобальном измерении воспроизведение фронтирной преступности объясняется механизмами развёртывания конфликта культур. В нацио наАьном - выявАено три виАа фронтирной преступности: транзитивно-, имманентно- и постмодерно-аномийная.

Оперирования фронтиром как категорией криминологического Аискурса открывает возможности Аля более гАубокого исследования детерминации политической преступности в Украине, а также Аля разработки стратегий общесоциа ьного развития (в том чис $е$ и в контексте противодействия преступности) с учетом фактора социокультурного пограничья Перспективными направлениями криминологического исс медования фронтира является изучение вАияния пограничья и межграничья на стимулирование экстремизма, терроризма учёта его значение при проектировании и проведении в жизнь концепции переходного правосудия, а также особенностей конституирования фронтирной идентичности как антикримина ььного базиса.

КАючевые слова: фронтир, социальный сценарий, наратив, Аискурс, символика, преступность, вражда.
Фронтир

як категорія кримінологічного дискурсу

ним маніпулювання доксою і т.д. Це підтверджує раніше висловлену тезу про фронтирну злочинність як різновид злочинності політичної.

Принагідно також зауважимо, що соціальні сценарії та відповідні фронтири, як засвідчує історія, не завжди випливають з об'єктивних процесів, а формуються "нашвидкоруч", мають суто маніпулятивне, пропагандистське забарвлення, завше при цьому апелюють до своєрідної інтерпретації історії, теорії та репрезентують новий вектор майбутнього. Більшовистсько-радянська класова боротьба, сталінська "культурна революція" - боротьба на фронтирі проти інакшого, проти "потойбічного". "Соловецкие острова были последним местом в России, где собралось общество, прилично говорящее на французском языке..." (Г. Ріттершпорн, мовою перекладу $)^{15}$. І ця теза зі всією наочністю демонструє спроби створити гомогенну когнітивну ситуацію у географічно немислимих масштабах. Фронтир визначає відмінності конгнітивних ситуацій та семантичних інструментів пізнання; коли люди говорять "різними мовами" (здебільшого у переносному значенні) з'являються недорозуміння, протиріччя, зростає соціальна дистанція. Тому фронтири завжди означають дистанціювання; зі збільшенням соціальної дистанції пропорційно зростає індекс дегуманізації, що легітимізує (функціонально) насильство. Задача ж кримінології в цьому аспекті - виявлення, опис фронтирів, фіксація їх динаміки, характеристика протиріч, що на них виникають, ідентифікація фронтирної злочинності та розробка рекомендацій щодо протидії їй. Фронтиром слід управляти, інакше він нав'язує всьому суспільству свої "правила гри";

2) виникнення внутрішньо-сценарних фронтирів як межі непорозуміння, а тому й культурних відмінностей, викликаних до життя відмінностями у темпах суспільних перетворень. Такі фронтири - суто постмодерне явище, зумовлене міжпоколінними розривами. Звернення до соціальної архаїки (у політичному, економічному, культурному житті) зумовлене потребою впізнання відомого на фоні наростаючих трансформацій, осмислення яких виявляється проблематичним через перенасичення інформаційного простору, постійний приріст інформації та потребу у такій же постійній реінновації аби залишатися "сучасником", жити у "дусі часу". Компенсація пришвидшення соціального часу постає спробою його гальмування через звернення частиною населення до звичних (минулих) наративів, дискурсів, символіки. Оригінальним 3 цього приводу є Л. С. Рубінштейн, який гостро рифмує відчуття вказаної тенденції (мовою оригіналу): “Слёз восторга не скрывая, развернув глаза назад, скажем мы: "Не надо рая, дайте нам привычный ад"»16. Цей міжпоколінний розрив схожий на транзитивно аномійний (у класичному розумінні Е. Дюркгейма). Але з єдиною відмінністю: постмодерна аномія стає нормою (аргументи для цього знаходимо у демографічному "законі 10 мільярдів" (С. П. Капіца) та феномену пришвидшення часу, багаточасовості одночасного (Ж. Дарріда, Р. Козеллек, Г. Люббе та ін.), а тому й відповідний фронтир - постійно присутнім чинником соціальної напруженості, конфліктності, криміногенності.

На жаль, мусимо констатувати наявність у планетарних масштабах і більш фундаментального, абсолютно неприродного фронтиру соціально-природничого. На сьогодні лишається загадкою, зауважує Г. Люббе, яким чином могла розвинутися культура байдужості до природи і яким чином разом з цим було втрачено почуття єдності історії природи та історії культури. При тому, що історичність природи та істо-

Dvoryane i aristokratiya v Solovetskih lageryah [Nobles and aristocracy in the Solovetsky prison]. Solovki. Entsiklopediya [Encyclopedia]. Retrieved from http://www.solovki.ca/camp_20/ danzas.php [in Russian]. (2020, April, 20).

16 Rubinshteyn, L. S. (2016) Prichinnoe vremya [Causal time]. Moskva, AST: CORPUS, 281 [in Russian]. 
ричність культури були відкриті одночасно й до XIX ст. мислилася єдність природи та культури (показовим є розташування один напроти одного будівель-близнюків Музею історії мистецтв та Музею природознавства у Відні). Відмінність у їх історичності - лише у способах трансферу інформації: в культурній еволюції - мовними та символічними способами, а в біологічній - генетичними ${ }^{17}$. Але, більше того, мова навіть не про байдужість. Як підкреслював Е. Фромм, ставлення людини до природи поступово стали глибоко ворожим. Первинно протиріччя було укорінене в самому бутті: людина є частиною природи та водночас, завдяки своєму розуму, здіймається над нею. Але з часом, від месіанського бачення гармонії між людиною і природою не лишилося й сліду; ми перейшли до експлуатації та підкорення ${ }^{18}$. Війна, що розгортається на цьому фронтирі, - однонаправлена, аутодеструктивної, омніцидної властивості, далеко не завжди (а фактично лише в мізерних масштабах і вузьких мисленнєвих, юридичних межах) визначається як злочинна, тобто у категоріях екологічної злочинності.

I справа тут у домінуванні привласнюючого над буттєвим мислення (деморалізації ринку, аксіологізації гедоністичних, егоцентричних установок, що підтримують ринок та провідний принцип сучасного господарювання - зростання виробництва), гострій кризі природничо-соціальної ідентичності, глобальної економіки, що передбачає експлуатацію природи як даність.

Сьогоднішнє природокористування, кримінальна та інша суспільно небезпечна (хоча це словосполучення тут доречніше буде замінити на інше - натурально небезпечна) експлуатація довкілля (в тому числі - забруднення) не узгоджена зі спільними, загальнопланетарними, природничо-уселюдськими засновками на життя. Необхідне оперування концептом уселюдства, що передбачає всі покоління - і минулі, і майбутні одночасно. Кожне наступне покоління має піклуватися про передачу майбутнім довкілля у кращому стані, ніж воно його отримало. Такі установки можливі виключно в межах віссі ідентичності "уселюдство група - індивід"; лише у цій зв'язці виникає суб'єкт - предикатна спайка "Людина - Природа", "Людина Є Природа" (у форматі субстанційної логіки, західна філософська традиція, у модусі бутmя, а не володіння) та "Людина у Природі, Природа у Людині" (у форматі процесної логіки, східна філософська традиція). Ця спайка спрямовує дискусію у юснатуралістичну площину, в якій знаходять свій ресурс всі без виключення галузі права, в тому числі й кримінальне.

Принагідно зауважимо на окремих осередках подібного мислення, що вже мають свої проявлені результати на публічному рівні артикуляції. Ще у 1987 р., на Міжнародному форумі “За без'ядерний світ, за виживання людства" було порушено питання (Д. С. Ліхачов, Н. Накамото) про необхідність розробки та прийняття як модельного на міжнародному рівні з подальшим ухваленням на національних рівнях кодексу прав тварин та інших об'єктів природи ${ }^{19} .21 .12 .2010$ р. в Болівії прийнято Закон "Про Матір-Землю" (Ley de Derechos de la Madre Tierra"), відповідно до якого за біосферою, дикою природою визнаються 11 невідчужуваних прав, включаючи право на життя, на здійснення життєвих циклів без людського втручання, на захист від забруднень, на підтримку балансу тощо 20

\footnotetext{
${ }^{7}$ Lyubbe, G. (2016) V nogu so vremenem. SokraschYonnoe prebyivanie v nastoyaschem [Keeping up with the times. Shortened stay in the present]. Moskva, Izd. dom Vyisshey shkolyi ekonomiki, 368-370 [in Russian].

18 Fromm, E. (2019) Imet ili byit? [Have or be]. Moskva, ACT, 18 [in Russian].

19 Libachyov, D. S. (2018) Zametki i nablyudeniya: Iz zapisnyih knizhek raznyih let [Notes and observations: From notebooks of different years]. SPb., Azbuka, Azbuka-Attikus, 348 [in Russian].

20 Ley de Derechos de la Madre Tierra: Ley № 071 De 21 De Diciembre De (2010). Retrieved from http://www.planificacion.gob.bo/uploads/marco-legal/Ley $\% 20 \mathrm{~N} \% \mathrm{C} 2 \% \mathrm{~B} 0 \% 20071 \% 20$ DERECHOS\%20DE\%20LA\%20MADRE\%20TIERRA.pdf [in Spanish]. (2020, April, 20).
} 
Наразі триває дискусія на рівні лейбористської партії у Великобританії про так звану програму 3D - декарбонізація, децентралізація i "розтоварювання" природних ресурсів, тобто відмова, перш за все, від сприйняття енергоресурсів - нафти, газу, води, вітру - як товарів. Це дуже сильно ламає економічну парадигму, і це вже не наукова дискусія, а політична ${ }^{21}$. Цілком зрозуміло, що великі економічні, ресурсодобувні (а від них й фінансово-ринкові) гравці створюють у зв'язку з цим тиск на всю епістему, залучаючи як витончені механізми багатоступеневої фільтрації альтернативних досліджень, так і більш прямолінійні, кримінальні інструменти впливу на корпорації, окремих акторів, що свідчить про "живучість", стійкість соціально-природничого фронтиру. Він продукує як безпосередні кримінальні практики природокористування, так і формує омніцидну опозицію. Подолання цього фронтиру - справа не лише кримінології.

\section{Висновки.}

1. Фронтирна злочинність - різновид злочинності, детермінованої кримінальними формами перебігу конфліктів у зоні соціальних фронтирів. Специфічні ознаки фронтирної злочинності: 1) є конфліктом ідентичностей; 2) має політичну та/або релігійну мотивованість, однак безпеково-домінантну й солідаризуючу мотивацію; 3) за характером агресивно-насильницька; 4) залежить від історичної та/або релігійно-догматичної (фундаменталістської) свідомості, спирається на механізми постпам'яті, радикалізований дискурс, актуалізовані меми, символи.

2. У глобальному вимірі відтворення фронтирної злочинності пояснюється механізмами розгортання конфлікту культур. Також прийнято вважати, що епоха Постмодерну явила світові нові картини його безструктурної будови зі стертими кордонами між об'єктом і суб'єктом пізнання, між суб'єктом і дискурсом, між колишніми метанаративами і т.д. Але світ, водночас, став підкреслено фрагментарним. Міжфрагментний простір з об'єктивною необхідністю виявляє зону відмінностей, фронтирів. На їх межі - тероризм, ксенофобія, політичний, релігійний, етнічний кримінальний радикалізм тощо.

3. У національному (внутрішньодержавному) вимірі виявляється три види фронтирної злочинності: транзитивно-, іманентно- та постмодерно-аномійна. При їх аналізі доречно звертатись до аналітичних схем теорії аномії (Е. Дюркгейм) у специфікації до розуміння багатовимірності соціального часу, сценарності суспільного розвитку. Фронтири відтворюються на межі наративів, дискурсів, символіки. Тому фронтирна злочинність - особливий тип мислення, мови, знаків вираження приналежності. Усебічне глибинне дослідження, моніторинг змін останніх важлива задача сучасної української кримінології.

4. Фронтир - не лише криміногенний хронотоп, простір формування й дії криміногенних факторів, а й зона інновацій, прогресивних соціальних трансформацій. Напруга, що народжується різницею потенціалів, може бути використана, вочевидь, по-різному: і для ураження стурмом, і для освітлення домівок, для виробництва; з нею можна боротися, а можна й корисно використовувати. Ба більше: брак фронтирів - один з потужних факторів світового краху (навіть не кризи) в умовах глобалізації, уніфікації не лише економічних, а й соціокультурних, цивілізаційних моделей життя. Адже відсутність фронтирів, гранична невиразність відмінностей у мисленні й моделях адміністрування життєдіяльності унеможливлює роботу функції "випускного клапану", що є вельми важливою при зростанні соціальної густоти (населення, інформації, капіталів). Продукування відмінностей й конструктивне підтримання фронти-

21 Bebeshko, T. A. (2018) Klimat - eto novaya ekonomika [Climate is a new economy]. Ekonomicheskaya pravda [Economic truth]. The 13-th of August. Retrieved from https://www.epravda. com.ua/rus/publications/2018/08/13/639456/ [in Russian]. (2020, April, 15). 
рів (мов, релігій, культур в цілому) - одна з базових умов відтермінування сингулярності.

Певна річ, це є можливим виключно при подоланні надмірного історицизму в стратегіях соціального розвитку, сприйняття пограничної державотворчої генези (статус якої анітрохи не применшує можливості формування спільної політичної ідентичності, поліфакторної, множинної національної креації) не у форматі меншовартісного заперечення, а як факту, що відкриває широкий горизонт міжкультурних взаємодій, потенціалу для розвитку. Формування ідентичності на фронтирі передбачає визнання (через саморефлексію) пограничної етіології, визнання унікальності та прогресивності її синтетичних форм, установок, мотивацій, в тому числі через позитивне заперечення традицій метрополій чи їх компліментарне сприйняття. А надто ця теза є актуальною для України, її внутрішніх фронтирів, використання яких далеко не завжди (практично ніколи) відбувається на засадах міжкультурного пієтету, засноване на експансіоністських мотиваціях, ресентименті.

Таким чином, оперування фронтиром як категорією кримінологічного дискурсу відкриває нові пласти більш глибинного дослідження детермінації політичної злочинності в Україні, а також можливості для розробки стратегій загальносоціального розвитку (в тому числі й в контексті протидії злочинності) з урахуванням фактору соціокультурного пограниччя. Перспективними напрямами кримінологічного дослідження фронтиру є вивчення впливу пограниччя та міжграниччя на стимулювання екстремізму, тероризму, урахування його значення при проектуванні та проведенні у життя концепції перехідного правосуддя, а також особливостей (напрямів, способів, механізмів, стратегій, політик) конституювання фронтирної ідентичності як антикримінального базису.

\section{References:}

Bebeshko, T. A. (2018). Klimat - eto novaya ekonomika [Climate is a new economy]. Ekonomicheskaya pravda [Economic truth]. The 13-th of August. Retrieved from https://www.epravda.com.ua/rus/publications/2018/08/13/639456/ [in Russian]. (2020, April, 15).

Berdnikova, O. V. (2002). Poslednik rubezh? [The Last Frontier]. Otechestvennyie zapiski [Domestic notes], 6 (7). Retrieved from http://www.strana-oz.ru/2002/6/ posledniy-rubezh [in Russian]. (2019, October, 12).

Chandler, A. Comparing Frontiers: A Scout Report. Retrieved from http://www.arthurchandler.com/comparing-frontiers [in English]. (2020, March, 15).

Chornovol, I. (2015). Komporatyvni frontyry: svitovyi i vitchyznianyi vymiry [Comparative frontiers: world and domestic dimensions]. Kyiv, Krytyka [in Ukrainian].

Debor, E. (1999). Obschestvo spektaklya [Performance society]. Moskva, Logos [in Russian].

Dvoryane $\mathrm{i}$ aristokratiya $\mathrm{v}$ Solovetskih lageryah [Nobles and aristocracy in the Solovetsky prison]. Solovki. Entsiklopediya [Encyclopedia]. Retrieved from http:// www.solovki.ca/camp_20/danzas.php [in Russian]. (2020, April, 20).

Filippov, S. O. (2019) Protydiia transkordonnii zlochynnosti: hlobalnyi kontekst ta realii Ukrainy: monohrafiia [Combating cross-border crime: the global context and realities of Ukraine]. Odesa. Feniks [in Ukrainian].

Fromm, E. (2019). Imet ili byit? [Have or be]. Moskva, ACT [in Russian].

Kravchenko, V. V., Musiezdov A. A., Filippova O. A. (2012) Predstavleniya o Pograniche i praktiki ih ispolzovaniya [Perceptions of the Borderland and the practice of their use]. Vilnyus, Evropeyskiy gumanitarnyiy universitet [in Russian].

Ley de Derechos de la Madre Tierra: Ley № 071 De 21 De Diciembre De (2010). Retrieved from http://www.planificacion.gob.bo/uploads/marco-legal/Ley\%20 N\%C2\%B0\%20071\%20DERECHOS\%20DE\%20LA\%20MADRE\%20TIERRA.pdf [in Spanish]. (2020, April, 20). 
Lihachyov, D. S. (2018). Zametki i nablyudeniya: Iz zapisnyih knizhek raznyih let [Notes and observations: From notebooks of different years]. SPb., Azbuka, Azbuka-Attikus [in Russian].

Lyubbe, G. (2016). V nogu so vremenem. SokraschYonnoe prebyivanie v nastoyaschem [Keeping up with the times. Shortened stay in the present]. Moskva, Izd. dom Vyisshey shkolyi ekonomiki [in Russian].

Orlov, Yu. V. (2020). Resentyment: shliakh vid zhertovnosti do zlochynnosti [Resentment: the way from victimity to crime]. Visnyk Kryminolohichnoi asotsiatsii Ukrainy [Bulletin of the Criminological Association of Ukraine]. 1 (22), 140-151 [in Ukrainian].

Panarina, D. S. (2015). Granitsa i frontir kak faktor razvitiya regiona i/ili stranyi [Border and frontier as a factor in the development of a region and / or country]. Istoriya i sovremennost [History and Modernity], 1 (21). Retrieved from https://www. socionauki.ru/journal/articles/265432/ [in Russian]. (2019, October, 15).

Papernyiy, V. Z. (1996). Kultura Dva [Culture Two]. Moskva, Novoe literaturnoe obozrenie [in Russian].

Plokhii, S. M. (2011). Mizh istoriieiu ta natsiieiu: Pavlo Robert Magochii i pereosmyslennia ukrainskoi istorii [Between History and the Nation: Pavlo Robert Magochiy and Rethinking Ukrainian History]. Krytyka [Criticism], Zhovten [October]. Retrieved from https://krytyka.com/ua/articles/mizh-istoriieyu-tanatsiieyu-pavlo-robert-magochiy-i-pereosmyslennya-ukrayinskoyi-istoriyi [in Ukrainian]. (2020, March, 15).

Plokhii, S. M. (2016). Brama Yevropy: istoriia Ukrainy vid skifskykh voien do nezalezhnosti [The Gates of Europe: History of Ukraine from the Scythian Wars to Independence]. Kharkiv, Knyzhkovyi klub [in Ukrainian].

Rubinshteyn, L. S. (2016). Prichinnoe vremya [Causal time]. Moskva, AST: CORPUS [in Russian].

Надійшла до редколегї 26.04.2020 